\title{
Thermal Decomposition of Device
}

National Cancer Institute

\section{Source}

National Cancer Institute. Thermal Decomposition of Device. NCI Thesaurus. Code C63286.

Problems associated with a discoloration or destruction as a result of thermal decomposition of the device. 